\title{
STUDIES REGARDING A GLUTAMINE-LIKE SUBSTANCE IN BLOOD AND SPINAL FLUID, INCLUDING A METHOD FOR ITS QUANTITATIVE DETERMINATION
}

\author{
BY MEYER M. HARRIS \\ WITH THE TECHNICAl ASSISTANCE OF ROSLYN T. ROTH AND RUTH S. HARRIS \\ (From the Department of Internal Medicine, New York State Psychiatric Institute and \\ Hospital, New York City)
}

(Received for publication January 18, 1943)

It has been pointed out by several investigators $(1,2)$ that glutamic acid is the only amino acid that produces an increase in oxygen consumption by brain tissue in vitro. It has also been suggested that glutamic acid may act as an ammonia carrier in cellular metabolism $(2,3)$. The in vitro experiments of Krebs (4) demonstrated that the enzyme glutaminase is present in various organs, such as brain, liver, kidney, and retina. He also showed that tissues containing the enzyme will synthesize glutamine, in vitro, from ammonia and glutamic acid in the presence of a source of energy, such as glucose. This does not occur if a source of energy, such as glucose, is absent from the substrate.

In view of our finding that the level of the amino acids in the blood is depressed during insulin hypoglycemic shock therapy in patients with mental disorders, we suggested (5) that the above mentioned mechanisms may be involved in this phenomenon. This and the following paper are reports of studies in support of this suggestion. They indicate that a substance with the properties of glutamine is present in blood and spinal fluid, and that it is affected by insulin hypoglycemia and also glucose administration. While this work was in progress, Hamilton (6), in a short communication, reported on the presence of a glutamine-like substance in blood plasma.

Earlier investigators have reported on some of the characteristics by hydrolysis of glutamine, glutamine derivatives, asparagine, and urea. Thierfelder (7) and his co-workers showed that gliadin, dipeptides and tripeptides of glutamine, and various acetyl derivatives of glutamine, split off ammonia at a much slower rate than glutamine in $\mathrm{N} \mathrm{H}_{2} \mathrm{SO}_{4}$, both on boiling and at $20^{\circ} \mathrm{C}$. for 18 to 24 hours.

Chibnall and Westall (8) also investigated the extent of hydrolysis at $100^{\circ} \mathrm{C}$. at different hydro- gen ion concentrations of asparagine as compared with glutamine, together with the effect of hydrolysis on the change in the quantity of alpha amino acids as determined by the Van Slyke nitrous acid method, since, when the amide group of glutamine is hydrolysed, ring formation takes place between the amino group and the carboxyl group which prevents the decomposition by nitrous acid. They suggested conditions in which a combination of both determinations would be suitable for the quantitative determination of glutamine and asparagine in a mixture of these substances in plant extracts. They pointed out that the presence of urea would introduce a certain amount of error which, however, could be corrected for if the quantity of urea were known.

Later, Vickery and his co-workers (9) also investigated the characteristics of hydrolysis of these two acid amides and developed a quantitative method for the determination of glutamine in plant extracts by the amount of ammonia liberated by hydrolysis at $\mathrm{pH} 6.5$ at $100^{\circ} \mathrm{C}$. for 2 hours. They pointed out that, although asparagine does not split off ammonia under these conditions, urea does and they also stated that other compounds might be present in crude plant extracts which might hydrolyze under the specified conditions and that therefore the results of such determinations should be interpreted with caution.

Krebs (4), in his studies on the formation of glutamine by glutaminase in various tissues, used the amount of ammonia liberated in $2 \mathrm{~N} \mathrm{H}_{2} \mathrm{SO}_{4}$ (approximately) at $100^{\circ} \mathrm{C}$. for 5 minutes as a measure of the amount of glutamine formed in his in vitro experiments. Since Chibnall (8) had shown that urea liberates 22.9 per cent of its total nitrogen content as ammonia in 2 hours in $\mathrm{N}$ $\mathrm{H}_{2} \mathrm{SO}_{4}$ at $100^{\circ} \mathrm{C}$., it is obvious that a small amount of urea must have decomposed under the 
conditions of Krebs' experiments although the amount was too small to vitiate his results.

Since the body fluids which we wished to investigate contained urea as one of the interfering substances and perhaps other compounds which might liberate ammonia, a more detailed study of the rate of ammonia formation from substances in some of the body fluids and of solutions of glutamine, urea, asparagine, and other compounds on hydrolysis in various acidities and at different temperatures was undertaken.

\section{PROCEDURE AND METHODS}

Ammonia was determined by Conway's method (10) of micro-diffusion analysis. The micro-diffusion cells used were the standard glass units as recommended by him. Standard acids of the proper ranges of normality containing Tashiro's indicator were prepared according to his directions. Kirk's standardized capillary burette (11) with a capacity of $0.1 \mathrm{ml}$. was used for titration. The method permits the determination of 2 to 5 gamma per $\mathrm{ml}$. of ammonia nitrogen with an accuracy of about 2 per cent and 0.4 gamma with an accuracy of about 5 per cent. Although Conway found that diffusion at $37^{\circ} \mathrm{C}$. for 1 hour allowed practically complete distillation of the ammonia contained in $1 \mathrm{ml}$. of solution, we found that where strong acid had been used in the preparation of the material and then neutralized with sodium hydroxide, 2 hours at $37^{\circ} \mathrm{C}$. was preferable, and this period of diffusion was therefore used in all determinations. One $\mathrm{ml}$. of the various solutions investigated was used for each analysis. Each determination was done in duplicate or triplicate.

The free ammonia present in the fluid and the reagents was determined prior to hydrolysis by addition of saturated $\mathrm{K}_{2} \mathrm{CO}_{3}$ and distillation at $37^{\circ} \mathrm{C}$. for 2 hours and titrating. By adding fresh standard acid to the central chamber of the Conway dish after the 2-hour period and allowing the distillation to continue for an additional 2hour period, titrating, and repeating this procedure several times, it was found that very small amounts of ammonia were given off both by aqueous glutamine solutions, and also the body fluids, due to decomposition of the amide by alkali. It was found that this continued at a slow constant rate in tests carried out at 2-hour intervals for 6 to 8 hours. Therefore, corrections for the ammonia, liberated by such decomposition, were made by adding fresh standard acid to the central chamber after each ammonia determination and allowing the distillation to continue for an additional 2 hours at $37^{\circ} \mathrm{C}$. The amount contributed from this source gradually decreases as the acid hydrolysis progresses and no additional ammonia is obtained by this procedure where the glutamine solution or the labile compound in the body fluid being analyzed has been completely hydrolyzed.1 Urea solution in saturated $\mathrm{K}_{2} \mathrm{CO}_{3}$ at $37^{\circ} \mathrm{C}$. does not liberate ammonia.

1 The maximum correction required due to the decomposition of unhydrolyzed glutamine or glutamine-like
Spinal fluid, 10 per cent trichloroacetic acid filtrates of plasma and serum, ultrafiltrates of serum and plasma, and solutions of glutamine, asparagine, and urea were investigated in this study. Ultrafiltrates of serum and plasma were prepared by filtration through Number 600 cellophane membranes at 30 lbs. pressure.

The rate of ammonia liberation on hydrolysis in 10 per cent trichloroacetic acid, $0.7 \mathrm{~N} \mathrm{HCl}$ or $\mathrm{H}_{2} \mathrm{SO}_{4}, \mathrm{~N} \mathrm{HCl}$ or $\mathrm{H}_{2} \mathrm{SO}_{4}$, and $2 \mathrm{~N} \mathrm{HCl}$ or $\mathrm{H}_{2} \mathrm{SO}_{4}$, with and without 10 per cent trichloroacetic acid, at temperatures of $40^{\circ} \mathrm{C}$., $50^{\circ} \mathrm{C}$., $60^{\circ} \mathrm{C}$., $70^{\circ} \mathrm{C}$., and $100^{\circ} \mathrm{C}$., at various time intervals, was investigated, as indicated in the tables and figures.

In comparing the rate of hydrolysis of the body fluids with that of the aqueous glutamine solutions, corrections were made for the slight amount of ammonia liberated by urea decomposition during acid hydrolysis, as will be indicated in the experiments.

\section{OBSERVATIONS}

\section{Ammonia liberated on acid hydrolysis by urea and spinal fluid}

In Figure 1 is shown the result of a preliminary study of the rate of liberation of ammonia nitrogen by normal spinal fluid heated at $60^{\circ} \mathrm{C}$., $70^{\circ} \mathrm{C}$., $80^{\circ} \mathrm{C}$., and $100^{\circ} \mathrm{C}$., in $0.7 \mathrm{~N} \mathrm{HCl}$ and $2 \mathrm{~N} \mathrm{HCl}$, and also by that of urea (33 $\mathrm{mgm}$. and $40 \mathrm{mgm}$. per $100 \mathrm{ml}$.$) , dissolved in similar acid solutions$ and heated at $80^{\circ} \mathrm{C}$. and $100^{\circ} \mathrm{C}$. Ammonia determinations were made every half hour for 4 to 6 hours. The ammonia liberated is calculated as milligrams of ammonia nitrogen per $100 \mathrm{ml}$. of original solution. It will be noted, Figure 1 (curve V), that at $70^{\circ} \mathrm{C}$., the ammonia liberated rises rapidly and tends to approach a plateau level in $1 \frac{1}{4}$ to $11 / 2$ hours. At $80^{\circ} \mathrm{C}$., the rise is somewhat more rapid than at $70^{\circ}$ during the first hour, and no similar plateau level is reached, the liberated ammonia rising slowly in practically a straight line over a 3-hour period beyond the first hour (Figure 1, curve IV). At $100^{\circ} \mathrm{C}$., the liberated ammonia rises most rapidly in the first half hour and then at a slightly slower but steady rate during the subsequent 4 to 6 hours of observation. At $60^{\circ}$, not shown in the figure, ammonia was liberated more slowly and reached a plateau level in 3 to 4 hours.

It is obvious that above $70^{\circ} \mathrm{C}$, , some substance besides that readily decomposed at $70^{\circ} \mathrm{C}$. or below, decomposes in appreciable amounts, this effect increasing with the increase in temperature.

substance by the strong alkali was about $0.06 \mathrm{mgm}$. of ammonia nitrogen per $100 \mathrm{ml}$. of solution. 


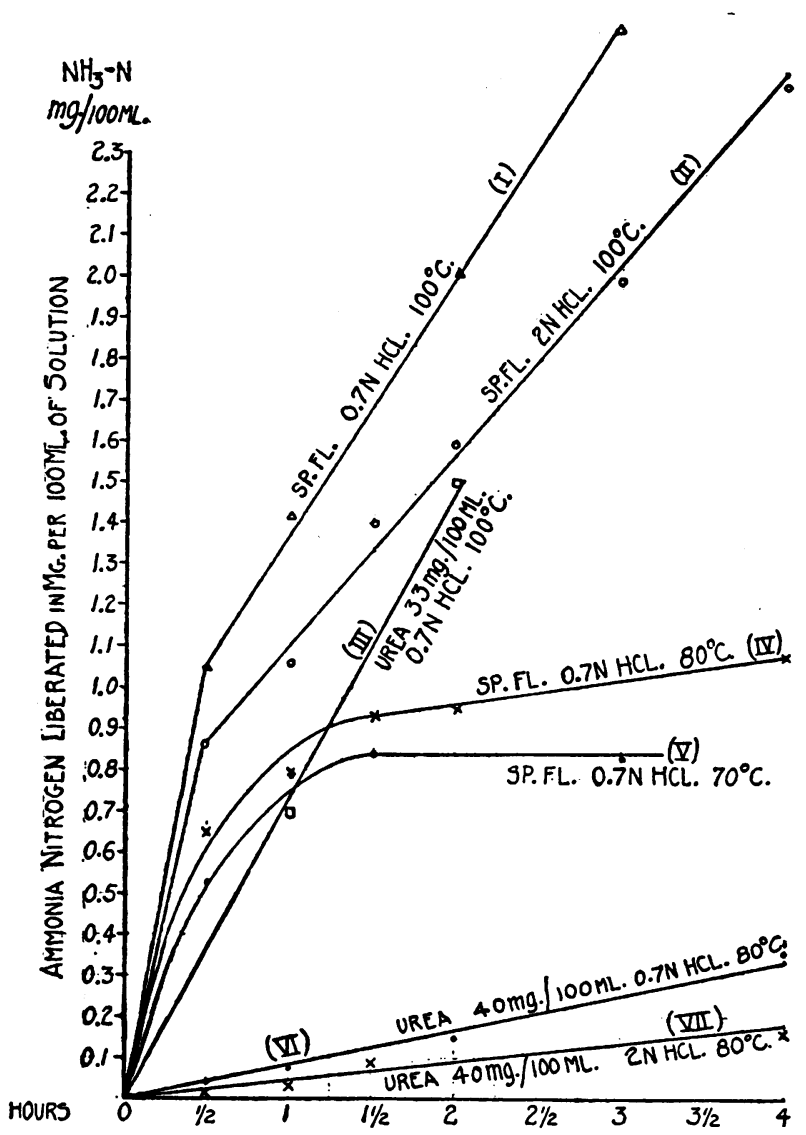

Fig. 1. Shows the Liberation of Ammonia on Acid Hydrolysis by Urea Solutions and Spinal Fluid IN $0.7 \mathrm{~N}$ ANd $2 \mathrm{~N} \mathrm{HCl}$ at $70^{\circ} \mathrm{C}$., $80^{\circ} \mathrm{C}$., ANd $100^{\circ} \mathrm{C}$.

The urea solution liberates ammonia at a slow steady rate at $80^{\circ} \mathrm{C}$. (curve VI) but at $100^{\circ} \mathrm{C}$. (curve III) the rate is very much more marked. ${ }^{2}$ At $70^{\circ} \mathrm{C}$. the amount of ammonia liberated by urea in $1 \frac{1}{4}$ hours is slight (Table I).

Since the spinal fluid contained $26 \mathrm{mgm}$. of urea per $100 \mathrm{ml}$., the steady slow liberation of ammonia at $80^{\circ}$ beyond the $11 / 2$-hour period could

2 It will be noted that the decomposition of urea is somewhat less in $2 \mathrm{~N} \mathrm{HCl}$ than in $0.7 \mathrm{~N} \mathrm{HCl}$. This is in keeping with the findings of Kreible and Holst (12) and Hammett (13) that in strong inorganic acid solutions, the decomposition of amides decreases with increase in strength of the acid, after a certain maximum point has been reached. The acidity at which the maximum rate of decomposition occurs was found to vary for different amides. The parallel behavior of glutamine and the glutamine-like substance in this regard is added evidence that the latter is probably glutamine. The findings of Vickery, et al. (9) that at $\mathrm{pH} 4$, at $100^{\circ} \mathrm{C}$., urea liberates very much more ammonia than at $\mathrm{pH} 6.5$, is in contrast, but is not incompatible with the above findings. practically be accounted for by the slow decomposition of its urea (compare curve IV with ammonia liberation by urea solution curve VI at $80^{\circ} \mathrm{C}$.). This also is true at $100^{\circ} \mathrm{C}$. (compare curves I and III of Figure 1) beyond the 1/2-hour period.

TABLE I

Decomposition of aqueous solutions of urea in 10 per cent trichloroacetic acid at $70^{\circ} \mathrm{C}$.

\begin{tabular}{|c|c|c|c|}
\hline \multicolumn{4}{|c|}{$\begin{array}{c}\text { Ammonia liberated, calculated as nitrogen per } 100 \mathrm{ml} . \\
\text { of original solution }\end{array}$} \\
\hline \multicolumn{2}{|c|}{ Time } & $\begin{array}{l}\text { Urea solution } \\
\text { (30 mgm. per } 100 \mathrm{ml} .)\end{array}$ & $\begin{array}{l}\text { Urea solution } \\
\text { (60 } \mathrm{mgm} \text {. per } 100 \mathrm{ml} \text {.) }\end{array}$ \\
\hline $\begin{array}{c}\text { hours } \\
1 \\
2 \\
3\end{array}$ & $\begin{array}{c}\text { minutes } \\
15 \\
30 \\
45\end{array}$ & $\begin{array}{c}\text { mgm. } N \text { per } 100 \mathrm{ml} . \\
0.05 \\
0.09 \\
0.12\end{array}$ & $\begin{array}{c}m g m . N \text { per } 100 \mathrm{ml} . \\
0.08 \\
0.16 \\
0.24\end{array}$ \\
\hline \multicolumn{2}{|c|}{$\begin{array}{l}\text { Average per } 1 \\
\text { hour and } 15 \\
\text { minutes }\end{array}$} & 0.043 & $\begin{array}{l}0.08 \text { or }(0.04 \mathrm{mg} . \mathrm{N} \\
\text { per } 30 \mathrm{mg} \text {. of urea } \\
\text { in } 100 \mathrm{ml} .)\end{array}$ \\
\hline
\end{tabular}

Rate of ammonia liberation on hydrolysis in 10 per cent trichloroacetic acid

Since it was planned to use trichloroacetic acid to deproteinize blood serum and plasma for investigation, the following studies were carried out.

(A) Ammonia liberated by urea in 10 per cent trichloroacetic acid solution at $70^{\circ} \mathrm{C}$.

In Table $I$ is shown the amount of ammonia nitrogen liberated by $30 \mathrm{mgm}$. and $60 \mathrm{mgm}$. of urea per $100 \mathrm{ml}$. of solution, in 10 per cent trichloroacetic acid, at $70^{\circ} \mathrm{C}$. It will be seen that, under these experimental conditions, $0.04 \mathrm{mgm}$. of ammonia nitrogen per $100 \mathrm{ml}$. is liberated in 1 hour and 15 minutes, per $30 \mathrm{mgm}$. of urea in $100 \mathrm{ml}$. of solution. This decomposition occurred at this steady rate for 3 hours and 45 minutes of observation. This datum will be used later for making corrections for the ammonia liberated by the urea present in the body fluids. It is obvious that this correction, which will be required for spinal fluid and blood from individuals without nitrogen retention, will be very small, since the urea present is usually below $30 \mathrm{mgm}$. per $100 \mathrm{ml}$.

(B) Rate of hydrolysis of glutamine and spinal fluid in 10 per cent trichloroacetic acid at temperatures of $50^{\circ} \mathrm{C} ., 60^{\circ} \mathrm{C}$., and $70^{\circ} \mathrm{C}$.

One part of an aqueous 40 per cent solution of trichloroacetic acid was added to 3 parts of an 
aqueous glutamine solution (freshly prepared) and to 3 parts of spinal fluid, in order to obtain 10 per cent trichloroacetic acid in the reaction mixtures without too great a dilution of the material being hydrolyzed. The protein precipitated in the spinal fluid was removed by centrifuging. The nitrogen liberated as ammonia on acid hydrolysis was calculated per $100 \mathrm{ml}$. of the original solution.

The results of experiments at $60^{\circ} \mathrm{C}$. and $70^{\circ} \mathrm{C}$. are shown in Table II. It will be seen that at $70^{\circ} \mathrm{C}$., the ammonia liberated both by glutamine and spinal fluid approaches a plateau level in 1 hour and 15 minutes. At $60^{\circ} \mathrm{C}$., a plateau level is not reached until about 3 to 4 hours.

In Figure 2 are shown the results of additional experiments of the rate of hydrolysis of glutamine and spinal fluid carried out at $50^{\circ}, 60^{\circ}$, and $70^{\circ}$ C., in 10 per cent trichloroacetic acid and $0.7 \mathrm{~N}$ $\mathrm{H}_{2} \mathrm{SO}_{4} \cdot \log \left(C_{0}-X\right)=\log C$ has been plotted against time $(\mathrm{t})$, in which $\left(C_{0}\right)$ represents the total amount of labile "amide" nitrogen at $t=0$, and $X$ represents the amount hydrolyzed in time ( $t$ ) of the glutamine or the labile substance in the spinal fluid, expressed in millimoles per liter. The latter figure was obtained from the ammonia liberated in 1 hour and 15 minutes at $70^{\circ} \mathrm{C}$. in 10 per cent trichloroacetic acid, and was corrected for the slight decomposition of urea and for free am- monia present prior to hydrolysis, as indicated earlier in the paper. The figures have also been corrected for the slight decomposition of glutamine or glutamine-like substance due to the strong alkali used to distill off the ammonia, as indicated previously in the section on methods. This correction (maximum about $0.06 \mathrm{mgm} . \mathrm{N}$ per 100 $\mathrm{ml}$.) decreases, as indicated previously, and approaches zero as the hydrolysis proceeds.

It will be seen from Figure 2 that glutamine and the substance in the spinal fluid decompose as a first-order reaction and that the slopes are practically identical for the 2 substances.

The reaction rate has also been studied in 10 per cent trichloroacetic acid plus $\mathrm{N} \mathrm{HCl}$ and $2 \mathrm{~N}$ $\mathrm{HCl}$. These also gave practically identical rates for the 2 substances under similar conditions of acidity and temperature. It should be noted, however, that the rate was found to be somewhat more rapid in the stronger acid solutions. This is similar to the increase in rate of acid hydrolysis of formamide, acetamide, and propionamide, observed with increase in strength of the inorganic acid solutions within certain ranges. A discussion of this effect is given by Kreibel and Holst (12) and Hammett (13). ${ }^{3}$

The values of $k$ (specific reaction rate), as determined from the slopes of the lines from Figure

8 See also footnote 2.

TABLE II

Comparison of hydrolysis of glutamine solution and spinal fluid in 10 per cent trichloroacetic acid at temperatures of $60^{\circ}$ and $70^{\circ} \mathrm{C}$.

\begin{tabular}{|c|c|c|c|c|c|c|c|}
\hline \multicolumn{8}{|c|}{ Ammonia liberated calculated as $\mathrm{NH}, \mathrm{Nitrogen}$ in $\mathrm{mgm}$. per $100 \mathrm{ml}$. of original solution } \\
\hline \multicolumn{4}{|c|}{$60^{\circ} \mathrm{C}}$. & \multicolumn{4}{|c|}{$70^{\circ} \mathrm{C}}$. \\
\hline \multicolumn{2}{|c|}{ Time } & Spinal fluid & Glutamine solution & \multicolumn{2}{|c|}{ Time } & Spinal fluid & Glutamine solution \\
\hline $\begin{array}{c}\text { hours } \\
0 \\
0 \\
0 \\
0 \\
1 \\
1 \\
1 \\
2 \\
3 \\
4\end{array}$ & $\begin{array}{r}\text { minutes } \\
15 \\
30 \\
45 \\
0 \\
15 \\
30 \\
0 \\
0 \\
0\end{array}$ & 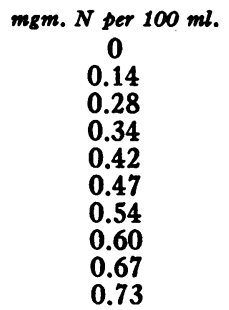 & $\begin{array}{c}\text { mgm. } N \text { per } 100 \mathrm{ml} . \\
0 \\
0.16 \\
0.34 \\
0.46 \\
0.55 \\
0.61 \\
0.65 \\
0.77 \\
0.89 \\
0.91\end{array}$ & $\begin{array}{l}\text { hours } \\
\text { 0 } \\
0 \\
0 \\
0 \\
1 \\
1 \\
1 \\
2 \\
3\end{array}$ & $\begin{array}{c}\text { minutes } \\
0 \\
10 \\
20 \\
30 \\
45 \\
0 \\
15 \\
30 \\
0 \\
0\end{array}$ & $\begin{array}{c}\text { mgm. } N \text { per } 100 \mathrm{ml} . \\
0 \\
0.25 \\
0.36 \\
0.48 \\
0.59 \\
0.69 \\
0.70 \\
0.70\end{array}$ & 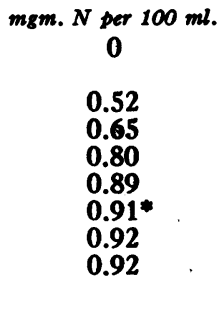 \\
\hline
\end{tabular}

* Nitrogen analysis (Kjeldahl) of the glutamine used yielded 18.7 per cent $\mathrm{N}$. Half of this would correspond to a maximum of 9.35 per cent of amide $N$ (theoretical $=9.6$ per cent). Since a solution of $10 \mathrm{mgm}$. of glutamine per 100 $\mathrm{ml}$. was used, 0.91 represents 97.3 per cent of the maximum amide nitrogen which might be expected to be liberated as ammonia, or 95 per cent of the theoretical content of glutamine. The glutamine was prepared from beet root by the method of Vickery, et al. It was recrystallized twice and had a melting point of $187^{\circ} \mathrm{C}$. (uncorrected). 


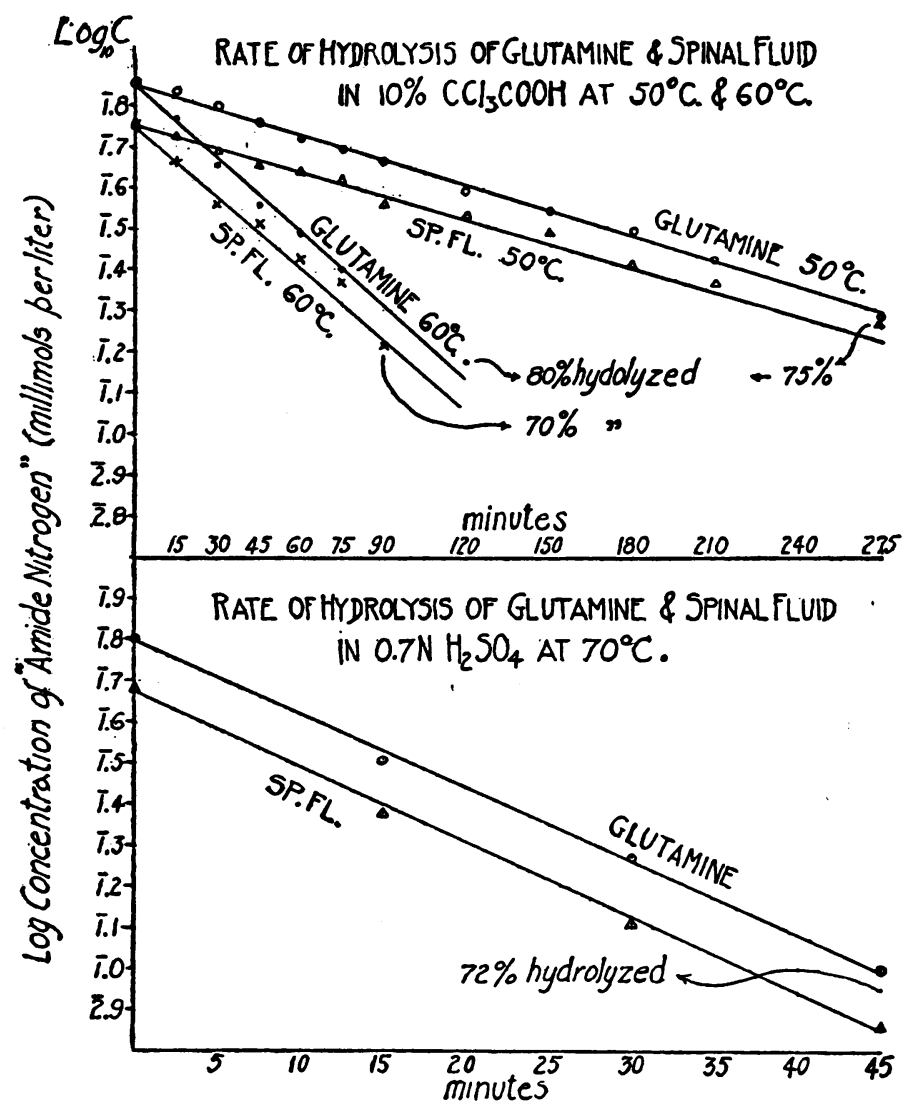

Fig. 2. Rate of Hydrolysis of Glutamine and Spinal Fluid in 10 Per Cent $\mathrm{CCl}_{2} \mathrm{COOH}$ at $50^{\circ}$ C. ANd $60^{\circ} \mathrm{C}$., and in $0.7 \mathrm{~N}$ $\mathrm{H}_{2} \mathrm{SO}_{4}$ AT $70^{\circ} \mathrm{C}$.

2 , are shown in Table III $\left(\log _{10} C_{0}-\log _{10} C=\right.$ $0.434 \mathrm{kt}$ ( $\mathrm{t}$ in seconds) was used in the calculations).

\section{Hydrolysis rates of ultrafiltrates and trichloro- acetic acid filtrates of serum and plasma compared with glutamine at $70^{\circ} \mathrm{C}$. in $0.8 \mathrm{~N}$ trichloroacetic acid}

One part of a $\mathbf{4 0}$ per cent trichloroacetic solution was added to 3 parts of serum or plasma in a 15 cc. graduated centrifuge tube. The mixture was centrifuged and the clear protein-free supernatant fluid was pipetted off. The protein precipitate was washed once with an amount of 20 per cent trichloroacetic acid approximately equal to $3 / 4$ of the volume of the compact protein precipitate, as measured in the graduated centrifuge tube. This was again centrifuged and the washing was added to the above supernatant fluid. This was made up to volume and aliquots were used for
TABLE III

Values of $(k)$ calculated from slopes of lines in Figure 2 $\left(\log _{10} C_{0}-\log _{10} C=0.434 k t\right)$ ( $t$ in seconds)

\begin{tabular}{c|c|c|c}
\hline \hline \multicolumn{1}{c|}{ Acidity } & Temperature & Substance & $k \times 104$ \\
\hline \multirow{2}{*}{10 per cent } & $50^{\circ} \mathrm{C}$. & Glutamine & 0.84 \\
$\mathrm{CCl}_{3} \mathrm{COOH}$ & & Spinal fluid & 0.74 \\
\cline { 2 - 4 } & $60^{\circ} \mathrm{C}$. & Glutamine & 2.30 \\
& & Spinal fluid & 2.22 \\
\hline $0.7 \mathrm{~N} \mathrm{HCL}$ & $70^{\circ} \mathrm{C}$. & Glutamine & 6.91 \\
& & Spinal fluid & 6.91 \\
\hline
\end{tabular}

study. A part of this material was titrated with methyl red as an indicator and the normality determined. This was found to be 0.8 normal. The glutamine was dissolved in trichloroacetic acid of the same normality. An aqueous solution of trichloroacetic acid was added to the ultrafiltrate to give the same acidity, the dilution of the ultrafiltrate being recorded. The ammonia liber- 
ated during the various stages of hydrolysis was calculated as nitrogen per $100 \mathrm{ml}$. of serum, serum ultrafiltrate, or glutamine solution, respectively. The necessary corrections for urea decomposition, etc., were made as previously described.

In Figure $3, \log _{10}\left(C_{0}-X\right)$ has been plotted against time, as previously described for spinal fluid. It will be seen that the decomposition is that of a first order reaction and that the slopes of the lines for glutamine, ultrafiltrate, and trichloroacetic acid filtrate are practically parallel.

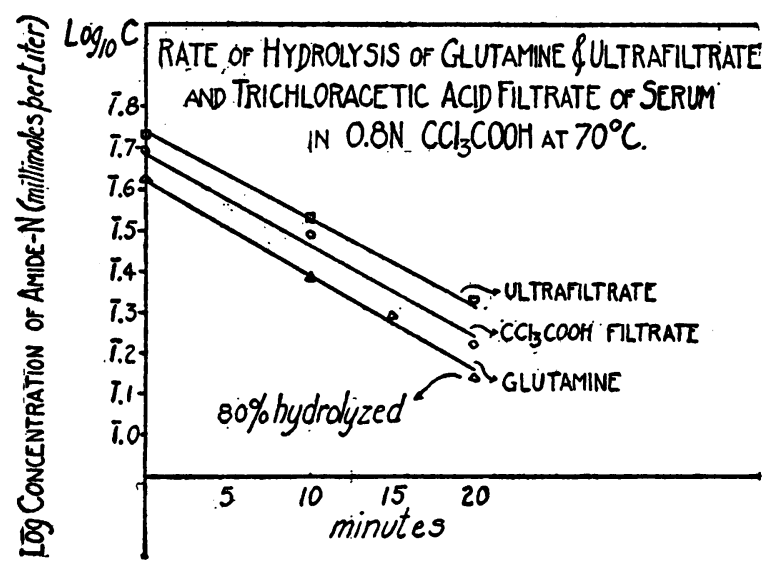

Fig. 3. Rate of Hydrolysis of Glutamine and Ultrafiltrate and Trichloroacetic Acid Filtrate of Serum in $0.8 \mathrm{~N} \mathrm{CCl}_{3} \mathrm{COOH}$ at $70^{\circ} \mathrm{C}$.

It will also be noted that the amounts of ammonia nitrogen liberated by the trichloroacetic acid filtrate of serum and by its ultrafiltrate in 75 minutes at $70^{\circ} \mathrm{C}$. are almost identical $(0.70 \mathrm{mgm}$. $\mathrm{N}$ per $100 \mathrm{ml}$. of serum and $0.75 \mathrm{mgm}$. $\mathrm{N}$ per 100 ml. of ultrafiltrate), thus showing that the substance yielding the ammonia is present in solution in the serum and does not result from the chemical treatment of the serum for protein precipitation.

Other experiments carried out in 10 per cent trichloroacetic acid and in $2 \mathrm{~N}_{2} \mathrm{SO}_{4}+10$ per cent trichloroacetic acid, at $50^{\circ} \mathrm{C}$., $60^{\circ} \mathrm{C}$., and $70^{\circ} \mathrm{C}$. showed the same parallel tendency in rate of hydrolysis between glutamine solutions, ultrafiltrates, and trichloroacetic acid filtrates of serum or plasma, for similar conditions of acidity and temperature. The data are not included since the findings are essentially the same as for spinal fluid.
Comparison of hydrolysis of glutamine and asparagine solutions and spinal fluid in 10 per cent trichloroacetic acid and in $2 N$ $\mathrm{H}_{2} \mathrm{SO}_{4}$ plus 10 per cent trichloroacetic acid at $70^{\circ} \mathrm{C}$. for $11 / 2$

\section{hours}

Asparagine solutions in 3 different concentrations, containing the equivalents of $8.0 \mathrm{mgm}$., 3.0 mgm., and $1.0 \mathrm{mgm}$. of amide nitrogen per $100 \mathrm{ml}$. of solution respectively, a glutamine solution with an amide nitrogen equivalent of $1.0 \mathrm{mgm}$. per 100 $\mathrm{ml}$. of solution, and spinal fluid were hydrolyzed in 10 per cent trichloroacetic acid and in 10 per cent trichloroacetic acid plus $2 \mathrm{~N} \mathrm{H}_{2} \mathrm{SO}_{4}$ at $70^{\circ} \mathrm{C}$. for $1 \frac{1}{2}$ hours. The results are shown in Table IV.

TABLE IV

Comparison of hydrolysis of glutamine, asparagine, and spinal fluid in 10 per cent trichloroacetic acid and 10 per cent trichloroacetic acid plus $2 \mathrm{~N}_{2} \mathrm{SO}_{4}$ at $70^{\circ} \mathrm{C}$. for $1 \frac{1}{2}$ hours.

Ammonia liberated, calculated as $\mathrm{NH}_{-}-\mathrm{Nitrogen}$ in $\mathrm{mgm}$. per $100 \mathrm{ml}$. of original solution

\begin{tabular}{|c|c|c|c|c|}
\hline Substance & \multicolumn{2}{|c|}{$\begin{array}{l}10 \text { per cent } \\
\mathrm{CCl} \text { COOH }\end{array}$} & \multicolumn{2}{|c|}{$\begin{array}{c}10 \text { per cent } \mathrm{CCl}_{3} \mathrm{COOH} \\
+2 \mathrm{~N} \mathrm{H}_{2} \mathrm{SO}_{4}\end{array}$} \\
\hline $\begin{array}{c}\text { Glutamine golution } \\
1.00 \mathrm{mgm} \text {. amide } \mathrm{N} \text { per } 100 \mathrm{ml} \text {. }\end{array}$ & $\begin{array}{c}\operatorname{mgm} . N \text { per } \\
100 \mathrm{ml} \\
1.00\end{array}$ & $\begin{array}{c}\text { per cent of } \\
\text { T.A.N. } \\
100^{*}\end{array}$ & $\begin{array}{c}\operatorname{mom} . N \text { per } \\
100 \mathrm{ml} \\
0.99\end{array}$ & $\begin{array}{c}\text { per cent of } \\
\text { T.A.N. } \\
99^{*}\end{array}$ \\
\hline $\begin{array}{l}\text { Asparagine solutions } \\
8.0 \mathrm{mgm} \text {. amide } \mathrm{N} \text { per } 100 \mathrm{ml} \text {. } \\
3.0 \mathrm{mgm} \text {. amide } \mathrm{N} \text { per } 100 \mathrm{ml} \text {. } \\
1.0 \mathrm{mgm} \text {. amide } \mathrm{N} \text { per } 100 \mathrm{ml} \text {. }\end{array}$ & $\begin{array}{l}1.19 \\
0.36 \\
0.15\end{array}$ & $\begin{array}{l}15 \\
12 \\
15\end{array}$ & $\begin{array}{l}3.40 \\
1.25 \\
0.39\end{array}$ & $\begin{array}{l}42 \\
42 \\
39\end{array}$ \\
\hline Spinal fluid & $0.73 \dagger$ & 100 & 0.74 & 102 \\
\hline
\end{tabular}

* Per cent of T.A.N. = Per cent of the total amide-N present in the original solution which was liberated as ammonia.

+0.73 is considered as the total amide- $N$ due to the glutamine-like substance in the spinal fluid.

It will be noted that there is a marked difference in behavior of the asparagine solutions as compared with that of the glutamine solution and spinal fluid in the two acidities. While the amide nitrogen of glutamine and of the glutamine-like substance in the spinal fluid is completely liberated as ammonia under both conditions, that of asparagine is split off to the extent of 12 to 15 per cent in trichloroacetic acid alone, and 39 to 42 per cent in trichloroacetic acid plus $2 \mathrm{~N} \mathrm{H}_{2} \mathrm{SO}_{4}$ during the same period of hydrolysis. It is apparent from the figures that if asparagine were present in the spinal fluid in an amount equivalent to the lowest concentration used in the experiment, it 
would have been readily detected by this procedure. 4

Comparison of the determination of amide nitrogen of glutamine solutions determined by different methods

Two solutions of glutamine, solution I containing 10 times as much glutamine as solution II, were used to compare the quantitative determina-

TABLE V

Comparison of various methods for quantitative determination of glutamine in terms of amide nitrogen

Amide nitrogen calculated as ammonia nitrogen liberated per $100 \mathrm{ml}$. of solution

\begin{tabular}{|c|c|c|}
\hline Method & Solution I* & Solution II* \\
\hline $\begin{array}{l}\text { Vickery et al. (Buffer solution pH } \\
6.5 \text { at } 100^{\circ} \text { C. for } 2 \text { hours) }\end{array}$ & $\begin{array}{l}\underset{100}{\operatorname{mgm}} \stackrel{N \text { per }}{\text { ml. }} \\
8.60\end{array}$ & 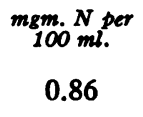 \\
\hline $\begin{array}{c}\text { Krebs }\left(2 \mathrm{~N} \mathrm{H}_{2} \mathrm{SO}_{4} \text { at } 100^{\circ} \mathrm{C} \text {. for } 5\right. \\
\text { minutes }) \\
\left(2 \mathrm{~N} \mathrm{H}_{2} \mathrm{SO}_{4} \text { at } 100^{\circ} \mathrm{C} \text {. for } 10\right. \\
\text { minutes })\end{array}$ & $\begin{array}{l}8.80 \\
9.05\end{array}$ & $\begin{array}{l}0.88 \\
0.89\end{array}$ \\
\hline $\begin{array}{l}\text { Hydrolysis in } 10 \text { per cent } \\
\mathrm{CCl}_{2} \mathrm{COOH} \\
70^{\circ} \mathrm{C} \text {. for } 1 \text { hour } 15 \text { minutes } \\
70^{\circ} \mathrm{C} \text {. for } 2 \text { hours } 30 \text { minutes }\end{array}$ & $\begin{array}{l}8.85 \\
8.95\end{array}$ & $\begin{array}{l}0.89 \\
0.90\end{array}$ \\
\hline
\end{tabular}

* Solution I contained 10 times as much glutamine as solution II. For percentage of nitrogen recovered, see legend for Table II.

tion of glutamine by the amount of ammonia liberated in 1 hour and 15 minutes at $70^{\circ} \mathrm{C}$. in 10 per cent trichloroacetic acid, with the method of Vickery (9), and the method used by Krebs (4). Vickery states that his method gave from 96 per cent to 103 per cent recoveries. The results show

\footnotetext{
4 Another procedure which was adopted in the quantitative determination of the glutamine-like substance in studies to be reported in the next paper was as follows: The amount of ammonia liberated in 10 per cent trichloroacetic acid at $70^{\circ} \mathrm{C}$., in 1 hour and 15 minutes and in 2 hours and 30 minutes, was determined. Since the ammonia liberated from glutamine or glutamine-like substance is practically complete in 1 hour and 15 minutes, under these conditions, the increase in ammonia occurring during the longer heating period is due to some other substance in the body fluid hydrolyzing at a slower rate than glutamine. This served as a check on the determination. Also, the difference in ammonia liberated between the 2 heating periods can be used to correct the figure obtained in the shorter heating period. This small correction can be accounted for, in whole or in very large part, by the slight decomposition of urea.
}

a very close agreement between the various procedures, the method of Krebs and our method giving slightly higher results (Table V).

\section{DISCUSSION}

Although the final proof that the glutamine-like substance present in blood serum and plasma and spinal fluid is glutamine will be chemical isolation and identification of the substance (a task which Hamilton (6) states he is pursuing), various facts indicate strongly that it is glutamine. These facts are as follows:

(1) Certain tissues in the body contain the enzyme glutaminase which can synthesize glutamine. (2) McIlwain (14) has isolated glutamine from horse meat. (3) The parallel behavior under the various conditions of hydrolysis of glutamine and the glutamine-like substance. (4) The observations of Hamilton (6) of the probable formation of pyrrolidone carboxylic acid by the glutamine-like substance in blood plasma.

We were so strongly inclined to the view, as a result of our studies, that the substance is glutamine and is probably of considerable importance, that we had proceeded to investigate the behavior of this substance in various clinical and experimental conditions. These data will be reported in subsequent communications.

Our findings are in agreement with those of Hamilton (6) that the amount of ammonia liberated on acid hydrolysis by this compound in blood plasma is equivalent to about 5 to $10 \mathrm{mgm}$. of glutamine per $100 \mathrm{ml}$. This we have found is also true not only for man but for the blood of the rabbit. This level is also found in human spinal fluid which may be considered as being, in a way, an ultrafiltrate of the blood. The level in blood and spinal fluid is, however, not fixed, but has been found to change with certain physiological and experimental conditions. Some of these phases of the work are still under investigation. The effect of insulin hypoglycemia and glucose administration are reported in the next paper.

\section{SUMMARY AND CONCLUSIONS}

1. Studies were made which indicate that blood plasma, serum, and their ultrafiltrates, and also spinal fluid, contain a substance which has the physicochemical properties of glutamine. 
2. Supporting evidence that the glutamine-like substance is probably glutamine is discussed.

3. A micro method for its quantitative determination is indicated.

\section{BIBLIOGRAPHY}

1. Weil-Malherbe, H., Studies on brain metabolism. I. The metabolism of glutamic acid in brain. Biochem. J., 1936, 30, 665.

2. Gerard, R. W., Metabolism of brain and nerve. Ann. Rev. Biochem., 1937, 6, 419.

3. Leuthardt, F., Uber den Stoffwechsel des Glutamins. Schweiz. med. Wchnschr., 1941, 71, 322.

4. Krebs, H. A., Metabolism of amino acids. IV. The synthesis of glutamine from glutamic acid and ammonia, and the enzymatic hydrolysis of glutamine in animal tissue. Biochem. J., 1935, 29, 1951.

Örström, A., Orström, M., Krebs, H. A., and Eggleston, L. V., The synthesis of glutamine in pigeon liver. Biochem. J., 1939, 33, 995.

5. Harris, M. M., Blalock, J. R., and Horwitz, W. A., Metabolic studies during insulin hypoglycemia therapy of the psychoses. Arch. Neurol. and Psychiat., 1938, 40, 116.

6. Hamilton, $P$., Glutamine-like substance in blood plasma. J. Biol. Chem., 1942, 145, 711.
7. Thierfelder, H., and von Cramm, E., Uber glutaminhaltige Polypeptide und zur Frage ihres Vorkommens im Eiweiss. Ztschr. f. physiol. Chem., 1919, 105, 58.

8. Chibnall, A. C., and Westall, R. G., The estimation of glutamine in the presence of asparagine. Biochem. J., 1932, 26, 122.

9. Vickery, H. B., Pucher, G. W., Clark, H. E., Chibnall, A. C., and Westall, R. G., The determination of glutamine in the presence of asparagine. Biochem. J., 1935, 29, 2710.

10. Conway, E. J., Apparatus for the micro-determination of certain volatile substances. The blood ammonia with observations on normal human blood. Biochem. J., 1935, 29, 2755.

Conway, E. J., Micro-diffusion Analysis and Volumetric Error. Crosby, Lockwood and Son, Ltd., London, 1939.

11. Kirk, P. L., Quantitative drop analysis (I). General apparatus and technique. Mikrochemie, 1934, 14, 1.

12. Kreible, V. K., and Holst, K. A., Amide hydrolysis with high concentrations of mineral acids. J. Am. Chem. Soc., 1938, 60, 2976.

13. Hammett, L. P., Physical Organic Chemistry. McGraw-Hill Co., New York, 1940, p. 365.

14. McIlwain, H., Fildes, P., Gladstone, G. P., and Knight, B. C. J. G., Glutamine and the growth of Streptococcus hemolyticus. Biochem. J., 1939, 33, 223. 